\title{
How Madoff Did It: Victims' Accounts
}

\author{
Lionel S. Lewis
}

Published online: 30 November 2010

(C) Springer Science+Business Media, LLC 2010

The art of acting is the art of impression management. One need not go to a theater, however, to see actors and acting. "All the world is a stage, and all of the men and women merely players," William Shakespeare wrote. Since Shakespeare, other dramatists have observed that individuals are able to nimbly shape reality. A character of the early twentieth century playwright Luigi Pirandello cogently makes this point: "Inevitably, try as we may, we make ourselves over. Let me explain. I come into this house, and right away-as far as you are concerned-I become the man that I am going to be - the man I have the possibility of being. I make myself over - that is to say, I present myself to you in a manner adapted to the relationship I am about to establish with you. And you do the same as regards me. But, after all, behind these two fictions which we set one opposite the other-behind the closed doors and the drawn shutters, so to speak, we keep our most secret thoughts, our most intimate feelings, hidden - everything, in short, that we are for ourselves outside the relationship which we intend to establish."

Impression management is the social process, sometimes conscious and sometimes unconscious, by which individuals control how others see and react to them. The attempt to influence the perceptions of others in social interaction is effected by regulating and controlling information. The theater aside, most people do not give the practice of impression management a great deal of attention in the presentation of self. Without artifice, they simply show others who and what they are. They are involved in

L. S. Lewis $(\bowtie)$

17 Morningside Lane,

Williamsville, NY 14221, USA

e-mail: socls1@buffalo.edu impression management, but they seldom consciously think about it. They simply put themselves on automatic pilot.

Since Erving Goffman's seminal work developing the concept of impression management, social psychologists have delineated its three instrumental goals: ingratiation (conveying happiness and pleasantness to elicit good will), intimidation (to get others to obey), and supplication (so that others will be helpful). Who someone is is largely in the eye of the beholder; yet this impression is often made through interaction. As Goffman saw it, all the world surely is not a stage, but the crucial ways in which it is not are difficult to specify.

In social interaction, individuals present or emphasize different aspects of themselves - for example, as a son or daughter, a wife or husband, an employee or employer, a father or mother, a close friend, a casual friend, etc.-in an assortment of settings. To the different audiences, each role is pretty much as it appears to be. It is precisely because it is a natural part of social life that people do not think too much of the art of impression management in the course of daily social life. Indeed, Goffman observed "that the arts of piercing an individual's effort of calculating unintentionality [deceit, feigning] seem better developed than our capacity to manipulate our own behavior...[that] the witness is likely to have the advantage over the actor, and the initial asymmetry of the communication process is likely to be retained." For the most part this is true, but it certainly would not be when one of the parties is working at deception, as is, for example, a con man. As Goffman notes, "we find that confidence men must employ elaborate and meticulous personal fronts and often engineer meticulous social settings.... The con man must carefully forestall the immediate impression that he might be what in fact he is." Professional actors also are practiced, on stage or off stage, at pretending they are something other than who they are. 
Surely, just about everyone manages his or her presentation of self from time to time. As was evident in the earlier discussion of the victim impact statements, some investors were very involved in managing their presentation of selfthey were victims and nothing more.

\section{An Unending Performance}

In light of the extensiveness of Madoff's fraud, he certainly had considerable capacity, using Goffman's term, of "calculating unintentionality." He particularly was a master at ingratiation and intimidation. If nothing else, he was what Goffman called a "disciplined performer": "someone who remembers his part and does not commit unmeant gestures or faux pas in performing it. He is someone with discretion; he does not give the show away by involuntarily disclosing its secrets. He is someone with 'presence of mind' who can cover up on the spur of the moment for inappropriate behavior.... And if a disruption of the performance cannot be avoided or concealed, the disciplined performer will be prepared to offer a plausible reason for discounting the disruptive event, a joking manner to remove its importance, or deep apology and self-abasement to reinstate those held responsible for it. The disciplined performer is also someone with 'self-control.' He can suppress his emotional response to his private problems...."

Madoff epitomized the disciplined performer. He was able to fool a great many people for a very long time. Indeed, his skill at impression management, at mastering the instrumental goals of impression management was, as this chapter documents, extraordinary. That is how he managed his Ponzi scheme so well for so long.

The overwhelming majority of Madoff's victims did not know him, had never met or seen him. Some had never even heard of him. They, of course, were not taken in by his manner. However, some of his victims did know him, some only casually, but some quite well. Accounts from these victims show that, without exception, Madoff presented himself as somebody other than what he was.

Not many victims who knew Madoff have spoken publicly about how they were caught in his web, how they had been duped. For some, it would be an embarrassment to do so. Yet, a handful have spoken or written of their experience as Madoff's clients. From these accounts a few themes have emerged which help explain Madoff's success until the world financial meltdown - not the discovery of his deceit or feigning-made it impossible for him to continue.

Madoff is often described as controlling, as wanting to be in command. Commanding perhaps; yet, most would not find Madoff dynamic or charismatic, in spite of the fact that he was surrounded by great wealth and the objects of great wealth-although one might expect this would enhance someone's image. He seemed more avuncular than awe inspiring. The only time he evidently attracted the attention of others was when they were attempting to convince him to let them invest their money with him, when they were, in effect, enabling him to steal their money.

He was more like a puppeteer, not in the center of action, but slightly removed. The distance he maintained gave him a vantage point, but kept him close enough never to lose control. The protective distance added to his mystery.

His seemingly random decisions not to accept some potential investors, while bewildering to those he rejected, augmented his reputation, making clients who had accounts with him feel special, part of a chosen fellowship. What now appears to be his practiced indifference or disinterest in attracting new business became part of his mystique, part of his allure. A schoolmate of Madoff's described to a Madoff biographer how this tactic ensnared him. After a 50 year hiatus, he called Madoff with some questions about where best to invest the proceeds from his recently sold business. Madoff threw out a few facts about his own asset management fund. "But when he [his childhood friend] popped the question about getting into the fund, Madoff declined. 'I can't,' he said. 'It's a closed fund.' At that, Bernie told him there was someone in the office who wanted to speak with him. He handed the phone to Ruth [his wife]." They chatted "excitedly," until she interrupted him in mid-sentence. "Bernie wants to talk to you again," she said.

Bernie took the phone back. "You know what ... we've known you a long time, and I'll open it up for you to come in.... But can you meet the minimum?" Bernie cited \$2 million. "I can meet that.... Do you mind if I bring others in with me, some family?" Not at all, Madoff said.

The childhood friend and his wife then "took Bernie and Ruth out to dinner."

Madoff was fully focused on managing his identity before he confessed, while many of his victims were involved in managing their identities after they learned that they had lost their investments, after they wanted to distance themselves from Madoff.

\section{Accumulated Advantage}

There is some question whether Madoff had fooled all of his clients. Not everyone who invested with him lost money. Many earned more than they had invested. A few, in fact, profited considerably, leading again to the question of who, besides Madoff, masterminded the fraud. 
By the time Madoff was sentenced, on June 29, 2009, government investigators were convinced that in spite of what he maintained in court, he surely had not acted alone. Legal proceedings had already begun against former employees who had helped produce false account information. Many believed it was not possible that some or all of his family members were not at least marginally involved. In fact, we might never know if all of Madoff's investors were unaware that his operation was fraudulent. Before reaching even a tentative conclusion regarding this question, it would first of all be necessary to know how many of Madoff's clients made money from their investments with him, who these clients were, and how much they earned. The investment experiences of just five individuals, Stanley Chais, Norman F. Levy, Peter Madoff, Jeffry Picower, and Carl J. Shapiro, suggest, if nothing else, that not all of Madoff's investors were being duped by him:

(1) In a complaint against Stanley Chais, a Californiabased investment adviser, the SEC alleged that from 1995 through 2008 he and his family members withdrew "approximately a half billion dollars more than they invested with Madoff." Chais had been a close friend of Madoff's for nearly 50 years. For almost 40 years, since establishing his business in the early 1970s, Chais and his family members had collectively almost fifty accounts with Madoff, and he "exercised direct or indirect control over more than sixty accounts at Madoff." Chais' funds yielded annual returns of between 20 and 25 percent, and purportedly did not have any returns of less than ten percent since at least 1995 . In one large fund, the total contributions were $\$ 105,761,000$ and the total withdrawals were $\$ 326,439,000$ (net profits= $\$ 220,678,000$ ); in a second fund, the total contributions were $\$ 45,729,000$ and the total withdrawals were $\$ 148,877,000$ (net profit $=\$ 103,148,000$ ); in a third fund, the total contributions were $\$ 9,541,000$ and the total withdrawals were $\$ 95,978,000$ (net profit= $\$ 86,437,000$ ). According to the SEC's court filing, "during the period 1995 through 2008, Chais, on his own behalf, as well as on behalf of his family members, withdrew at least $\$ 545,992,000$ more than they invested with Madoff." Chais also charged clients an annual fee of twenty five percent of their profits which were greater than ten percent. This amounted to almost \$270 million from 1995 to 2008 .

In addition, the government alleged that in the late 1990s Chais told Madoff that he did not want there to be any losses in the trades of his funds: "Madoff complied with Chais' request. Thus, between 1999 and 2008, despite purportedly executing thousands of trades on behalf of the funds, Madoff did not report a loss on a single (emphasis in original) equities trade."

(2) According to a court filing by the trustee for the SIPC, the New York real estate developer Norman F. Levy and his family's charitable foundation had withdrawn \$305 million more from the Madoff firm than they had placed in it since the mid-1970s. Levy died in 2005. (After his death, Madoff said in a paid newspaper advertisement: "My mentor and dear friend of 40 years. Your spirit and love of life have touched and changed all who knew you. You taught me so much. I'll cherish our relationship forever.") According to an SIPC court filing, as one of the executors of Levy's estate, Madoff transferred \$220 million of it to his own company and, "of course, that money was lost...." To settle the government's claim, Levy's adult children voluntarily returned an additional \$220 million to benefit Madoff's victims. (Over the years, a foundation Levy had established had given $\$ 84$ million to charity.)

(3) Peter Madoff, Bernard Madoff's brother, was the investment company's senior managing director and chief compliance officer. An attorney, he began working for his brother in 1965 . According to a court filing by the bankruptcy trustee, Peter Madoff had two accounts with the investment company in which he had invested $\$ 32,146$. Over the years, he redeemed $\$ 16.25$ million from these accounts. Between September 2005 and April 2006, he redeemed over $\$ 3.2$ million alone. On April 14 and June 2, 2004, \$4.45 million was wired to him in connection with the purchase of an apartment. Madoff Securities International Ltd. even paid almost $\$ 275,000$ for the purchase and restoration of his Aston Martin automobile. Between 2001 and 2008, he was paid over \$20 million in salary and bonuses working for his brother.

(4) From 1996 through 1999, the returns for two of the philanthropist Jeffry Picower's investments with Madoff generated annual rates of return of over 100 percent. (Like Chais and Levy, Madoff and Picower had been friends and business associates for a number of decades.) According to the SIPC trustee, between 1996 and 2007, 24 Picower "regular trading accounts enjoyed 14 instances of supposed annual returns of more than 100 percent," and 25 instances in which "the annual returns purportedly exceeded fifty percent." During this period, the annual rate of returns for a few accounts ranged from 120 percent to over 550 percent. One account was purported to earn over 950 percent in 1999. Moreover, there were cash withdrawals from Picower's account "ranging from $\$ 50$ million to $\$ 150$ million five or more times a year from 1995 through 2007 , for a total of $\$ 5,771,339,795$." 
(From 1996 to 2003, Picower and his wife received sums at the beginning of each quarter that grew from $\$ 330$ million to $\$ 1$ billion.) Overall, the Picower accounts' average annual rate of return between 1996 and 2007 was approximately twenty two percent.

In one egregious instance, according to the SIPC trustee, in April 2006, Picower wired a check for $\$ 125$ million to Madoff. Within 2 weeks, the $\$ 125$ million had purportedly grown to $\$ 164$ million, for a return of thirty percent (or $\$ 39$ million). Five months later, Picower withdrew the $\$ 125$ million, leaving $\$ 81$ million in this account. According to the court filing, the reason for this massive gain is that the "customer account statement reflected fifty seven purported purchases of securities between January 10 and January 24, 2006, almost 3 months before the account was opened or funded."

Picower is said to have profited by approximately $\$ 7.2$ billion from his investments with Madoff, including $\$ 6.746$ billion from 1995 to 2008. This would appear to make him the biggest beneficiary of Madoff's Ponzi scheme. The SIPC trustee liquidating Madoff's assets filed a lawsuit against Picower seeking the return of most of those profits. Ten months after Madoff was arrested, however, Picower's body was found at the bottom of his pool in Palm Beach, Florida, making it impossible, as one attorney said, to "hear from his own words whether he was complicit" or was as surprised as everyone else to learn about Madoff's Ponzi scheme. In its suit against Picower, the SIPC simply argued that the many transfers of funds from Madoff to Picower "were, in part, false and fraudulent payments of nonexistent profits supposedly earned."

(5) Carl J. Shapiro, the Boston women's apparel manufacturer, was another of Madoff's notable beneficiaries. Shapiro was one of Madoff's oldest friends, their friendship dating to when Madoff founded his business, with Shapiro being a crucial early benefactor. In 1960 , he gave Madoff $\$ 100,000$, at that time a huge sum, to invest, and when he sold his women's clothing company in 1971, he and his family foundation invested much more with Madoff's growing enterprise. Over the years, his accounts with Madoff eventually grew to $\$ 1$ billion. In a court filing, the SIPC trustee claimed that during the long relationship between Madoff and Shapiro, the latter enjoyed "unrealistic and consistently purported high rates of return and remarkable purported trading success." The question is, of course, were these allegedly false profits invented by Madoff? (Shapiro gave a large amount of his fortune to charity. According to tax records filed through 2007, Shapiro and his family foundation donated almost \$200 million to Brandeis
University, Harvard Medical School, Beth Israel Deaconess Medical Center, Brigham and Women's Hospital, the Boston Museum of Fine Arts, the Boston Symphony Orchestra, Wellesley College, and dozens of other charities.) Just weeks before Madoff's Ponzi scheme was exposed, Shapiro sent $\$ 250$ million to him, which, of course, was not enough to forestall the inevitable.

To make all of this seem plausible might require a considerable amount of impression management.

Taken together, these data suggest that Madoff was not a Robin Hood, robbing the rich and aiding the poor. Most important, he was not driven to crime. He stole from those he knew; he stole from strangers. He stole from gentiles; he stole from Jews, leading many to mislabel his theft an affinity fraud or an affinity Ponzi scheme. He stole from those who did good works through philanthropy with their money; he stole from those who did not. And as this material makes clear, after he took from the comfortable (the almost rich and nearly rich) and very comfortable, he gave to the extremely wealthy.

One consequence of Madoff's Ponzi scheme was to make manifest a faultless example of the Matthew effect (from the Gospel of Matthew 25:29, "for to all those who have, more will be given, and they will have an abundance; but from those who have nothing, even what they have will be taken away"), whereby those at the top are able to leverage their power and resources to gain more power and resources. To reduce their income subject to taxation, from time to time friends of Madoff advised him how much they wanted their accounts to grow in any period.

Parenthetically, Madoff worked actively to enhance the potency of the Matthew effect. Like others with financial resources, he used them to attempt to buy influence with lawmakers. He and his wife gave $\$ 238,200$ to federal candidates, parties, and political committees between 1991 and 2008, almost ninety percent of it going to Democrats. Moreover, between 1999 and 2008, his firm spent between $\$ 400,000$ and $\$ 590,000$ for Washington lobbyists.

\section{The Madoff Mystique}

The following accounts of five victims who knew Madoff professionally or personally will further our understanding of his success.

Michael Bienes For more than two decades beginning around 1970, until forced to shut down by the government in 1992, Bienes and his partner in an accounting firm, 
Frank Avellino, passed money directly to Madoff. More than a decade before Madoff's Ponzi scheme collapsed, Bienes retired to Florida and became a philanthropist.

In an interview with a television reporter, Bienes recalled first meeting Madoff: "But when I went downtown for the first time to deliver some papers to Bernie.... He walked in, Bernie, and it was like you were subsumed by him. He had an aura about him - a confidence the way he was set up, the way he looked, the way he spoke. The self-confidence-he just evoked confidence in you, that he knew he was in control, and if he was around, everything was fine. And then when he moved to his new office building, I used to go down there, One Wall Street. He had a whole floor. Wow. Wow. Wow."... Bienes describes Madoff during the early years that they worked together: "He wore the best shirts and always French cuffs. Beautiful. He just had a body that was right, that was set up perfectly. He had the body of an actor. You know what I mean - that he set himself up right. He looked right." There was no question in Bienes' mind that from the beginning (from a very young age) Madoff was "successful."

But when I really got to know him, he had a whole floor at One Wall Street, and a trading room, and it was all beautiful and set up nice. And he had a private office. And he had a big conference room and great views. He was Bernie. He was the guy. Bernie was the guy. When he walked into a room, he was the guy.

And I was in awe of him.

When asked about working with Madoff, Bienes said that there was "a lot of contact" between him and Madoff. When next asked, "so, you knew Bernie very well?," he responded: "I don't think anyone could know Bernie very well. We knew him."

In the interview, Bienes recalled his final business meeting with Madoff.

"So I said: 'Bernie, I'm sorry. I'm just a very scared person. And let's forget what I said and go on with this. I apologize."'

"He intimidated you."

"Yes."

"He scared you. Why?"

"Because he's Bernie Madoff."

Finally, in response to the question "and you never suspected that he was up to no good?" "Up to no good? He was a god. He was my life."

A month later, Bienes rhetorically asked a newspaper reporter: "Doubt Bernie Madoff? Doubt Bernie? No. You doubt God. You can doubt God, but you don't doubt Bernie." He repeated that it had been his impression that Madoff was "a brilliant investor" who "had that aura about him." And, again, in another conversation Bienes makes the same points:
It was a lunch, a buffet lunch.... And I remember my partner, Frank Avellino, and myself and Bernie meeting in the middle of the dance floor, and we were saying, "Thanks for having us," and he said, "Hey, come on-we're family, aren't we?" And at that moment he had me. He had me. We were family. Oh, my God! I was in! It really took me because he had a presence about him, an aura. He really captivated you. What Bienes took as unreserved acceptance completed his enchantment.

Client \#18 Thirteen months after Madoff was sent to prison, Client \#18, a former employee, sent me his "thoughts about Bernie": "Working at Madoff felt like a family atmosphere. Bernie knew the name of everyone who worked there - from the department heads all the way down to the mail room. He would walk around the office (not sit in his 'ivory tower' like most executives). He would joke around, and make fun of you and generally be friendly to everyone. Make no mistake - he was the boss. He was a perfectionist and expected perfection from everyone. He would have no trouble letting you know when you screwed up."

But, in general, Bernie was an approachable man. The door to his office was open-literally and figuratively. One never felt they would just walk in there at any time, but given a large enough issue, you always felt you could go to him. He was very much like an old patriarch. Not necessarily one you would sit down and have drinks with, but one you could go to if the need arose. You never heard personal stories from him and never heard about parts of the business you weren't supposed to. He was very compartmentalized in that way.

Bernie treated his employees very well-benefits, parties, bonuses, etc. Everyone looked up to him and respected him. That's why there was very little turnover there. Most employees who worked there were there for years-even decades.

Carmen Dell'Orefice Dell'Orefice, a supermodel whose face is more recognizable than her name, first appeared on the cover of Vogue in 1946, at the age of 15. For a dozen years, Dell'Orefice was the companion of Norman F. Levy, often described as Madoff's "best friend," and she, Levy, Madoff, and Ruth Madoff spent a great deal of time vacationing, socializing in New York, Palm Beach, and the south of France, and celebrating birthdays and holidays together....

For a long profile in Vanity Fair magazine, she described her first meeting with Madoff: "And there was a little man sitting behind a very big desk...." His mouth was pursed in his trademark smirk. At that meeting, Levy invested \$100,000 for her in Madoff"s "exclusive fund," an "honor," she was 
told, that Madoff did not bestow on everyone. She immediately joined Levy as part of Madoff's inner social circle.

Levy commonly referred to Madoff as his "son" (as did the textile tycoon Carl J. Shapiro). Madoff always deferred to Levy. No effort was too much to cultivate Levy's friendship. He took care of all the arrangements when the foursome traveled, even planning special excursions and finding and hand-delivering Levy's favorite ice cream. He oversaw the building of Levy's yacht. He hired bodyguards to protect against pirates. Whatever Madoff was doing, "I think of him as always smiling," Dell'Orefice said. She saw him as "quiet and caring," "shy, but so sure of himself." The Madoff she knew was generous and unassuming.

After the facts of Madoff's crime became public, Dell'Orefice could not believe that this was the same man she had spent so much time with, a man she saw as giving and pleasant. Obviously, Madoff had effectively concealed that he was capable of such a large and elaborate personal betrayal, of looting the fortunes of close friends who had used their network of friends to further his career.

Sheryl Weinstein Weinstein and Madoff were friends for two dozen years, and, according to her account, lovers for five of those. She had invested and lost her own savings with Madoff, and was one of those who denounced him at his sentencing trial. (She also invested much of the endowment of a charity, for which she was the chief financial officer, with Madoff but without ruin.) She also wrote a 200-page book detailing her friendship and (putative) romance with Madoff.

Weinstein portrays Madoff as shy, retiring. She too saw him as quiet and withdrawn. She reported that even her husband found him "unassuming, a very nice guy." What intrigued her about him "was an element of mystery" behind his gentle smile. ("Bernie greeted me warmly with the smile I'd grown fond of.") Although generally "kind," there was "toughness about him": "he had a rough-diamond persona."

Madoff "rarely showed emotion," he was always in control as when he was convincing her to invest with him.

"He reached across the table and stroked my hand. 'It's my company, Sheryl. I make the rules. And for you, I'd be willing to make an exception.'..."

"Bernie made it sound so logical. 'I understand,' he said.... 'If you want your money invested, you go to the best investment broker available...." Little did she know how accurate was her observation that "I felt that this man didn't reveal himself to others."

Weinstein concluded, "I think it was more important to Bernie to keep up the façade, the image at all costs and no matter what the moral implications.... It was about Bernie and who Bernie had to be to the world."
Elie Wiesel The Holocaust survivor, author, and Nobel Prize recipient lost approximately $\$ 37$ million in Madoff's Ponzi scheme-perhaps more than $\$ 20$ million of his personal assets and $\$ 15.2$ million from the endowment of his charitable foundation, the Elie Wiesel Foundation for Humanity.

In a panel discussion hosted by Conde Nast Portfolio and in an interview on National Public Radio, Wiesel described Madoff as having "imagination," an imagination "capable of anything." He had met Madoff about 20 years previously through a friend, who, in turn, was a very close friend of Madoff, having known him for 50 years. The friend described Madoff as "so great and so good.... And that's how we came to him."

Madoff gave the impression that he was making an exception by allowing Wiesel to invest with him. Wiesel thought quite highly of Madoff after they first had dinner together. One thing Wiesel remembered is that the topic of money never came up. They talked about ethics and education. Madoff "presented himself as a philanthropist. He gave money to other institutions.... There was a myth he created around him. Everything was so special, so unique, that it had to be secret. It was like a mystical mythology that nobody could understand." Madoff "also gave the impression that maybe 100 people belonged to the club." Moreover, "everybody told us in the field of finances, you can do much more....because of Mr. Madoff, the savior." Wiesel admitted that he bought into the Madoff mystique, that he was charmed. He was not the only one taken in by the veneer of exclusivity.

Madoff even tried to persuade Wiesel to give up his academic position at Boston University and move to Queens College: Panelist: "He wanted you to go to Queens College?" Wiesel: "Because his wife went to Queens College so they wanted to establish a chair, a special chair for me."

We thought he was God, we trusted everything in his hands.

Not only publicly, but also privately, Madoff was not what he appeared to be.

\section{In Pursuit of the American Dream}

There is nothing here to suggest that Madoff was in any way sui generis. In real life and fiction one can readily find countless examples of those whose lives are pretense. One such fictional character is F. Scott Fitzgerald's Jay Gatsby, the Great Gatsby. There are a number of interesting parallels between Gatsby and Madoff. Like Madoff, Fitzgerald's Gatsby is a mysterious figure. Unlike Madoff, to everyone Gatsby is a memorable figure, a handsome presence. 
To be sure, Gatsby is a truly memorable portrait of someone practiced in the art of impression management. In a pivotal scene, the first time Gatsby is visiting Daisy and Tom Buchanan's house, Daisy “cried 'you look so cool.' ... 'You always look so cool,' she repeated," and it is these words that give her husband an insight into the true nature of her relationship to Gatsby.

Gatsby (born James Gatz of North Dakota into a family of modest means), the source of whose wealth is dubious, is the subject of endless fascination to his neighbors and the guests at his lavish parties. He is rumored to be a war hero, a spy, and a bootlegger. He describes himself as "an Oxford man."

"'Well, they say he's a nephew or a cousin of Kaiser Wilhelm's. That's where all his money comes from.... I'm scared of him. I'd hate to have him get anything on me."

"'Someone told me they thought he killed a man once.'.... 'I don't think it's so much that,' argued Lucille skeptically; 'It's more that he was a German spy during the war.'... 'You look at him when he thinks nobody's looking at him. I bet he killed a man."

" One time he killed a man who had found out that he was nephew to von Hindenburg and second cousin to the devil. Reach me a rose, honey...."

As the gossip swirled, Gatsby invented an almost equally colorful past. Here is his response to his probing friend, Nick Carraway, the novel's narrator:

"'What part of the Middle West?' I inquired casually.

'San Francisco.'

'I see.'
'My family all died and I came into a good deal of money.'...

'After that I lived like a young rajah in all the capitals of Europe-Paris, Venice, Rome-collecting jewels, chiefly rubies, hunting big game, painting a little...."

Although Gatsby eventually tells Carraway something about himself, much of what Carraway ends up knowing he learns after Gatsby's death.

Both Gatsby and Madoff manufactured their past and present. What they do not fictionalize others invent. Both inspire awe, but in reality they are charlatans trying desperately to escape a commonplace existence. Both have worked diligently to reinvent themselves. Gatsby falsely claimed a background of privilege; Madoff falsely claimed one of impoverishment. Both Gatsby and Madoff were able to amass wealth to change their world, to live out a dream. For Gatsby, the wealth was the means to an end-to rekindle his romance with Daisy. For Madoff, the wealth seemed only to be an end in itself. In the end, their dreams are dashed, Gatsby's by violent death and Madoff's by his admission of fraud and imprisonment for life.

Lionel S. Lewis (A.B., Washington University; M.A., Cornell University; Ph.D., Yale University) is professor emeritus of sociology, SUNY/Buffalo. He is the author of 5 books and the author or coauthor of 130 research articles, essays, and reviews, a number published in SOCIETY. This article is the third in a planned series on the Madoff Ponzi scheme. 